\title{
A Novel Work on Training and Development
}

\author{
S. Praveen Kumar, CS Gowtham Chakravarthi
}

\begin{abstract}
In the advanced universe of innovative changes the requirement for preparing is progressively perceived in order to keep the workers in contact with new improvement. Each worry has an orderly preparing project. Preparing is the way toward giving workers explicit aptitudes or helping them to address insufficiencies in their exhibitions. It includes methodical techniques for moving specialized expertise to the workers in order to build their insight and abilities for doing explicit occupations with capability. Improvement is a push to furnish workers with the capacities the association required later on. It includes learning and abilities securing to boost the representatives want to perform employment well.
\end{abstract}

Keywords: Training; Development; Performance; Efficiency; Productivity

\section{INTRODUCTION}

Preparing and improvement is one of the basic piece of any association .It offices the development and advancement of the association through worker improvement. Without preparing and advancement no association can consider their development. A legitimate preparing and advancement program inside an association is profoundly fundamental in the present date[1],[3],[5].

It tends to be just clarify as the procedure by which an association give the fundamental expertise and essential thought regarding their obligation and duties . This task comprises of a portion of the thoughts and actualities about preparing and improvement inside IMFA[2],[4],[6], Therubali .Here in this undertaking I attempt to discover a portion of the down to earth effect of preparing and advancement on representatives by inquiring about in a commonsense field

\section{A. Human Resource}

Human asset is an undeniably widening term with which an association or other human framework portrays the blend of generally regulatory work force capacities with procurement and utilization of aptitudes, learning and experience, worker relations and asset arranging at different levels. The fundamental elements of $\mathrm{HR}$ are as per the following[7],[9],[11]:

- To deal with the workers inside association.

- To start appropriate human asset arranging.

Revised Manuscript Received on July 22, 2019.

Dr S. Praveen Kumar, Department of MBA, Bharath Institute of Higher Education and Research, Chennai, India.

Email: praveenkumar.mba@bharathuniv.ac.in

Mr.CS Gowtham chakravarthi, Department of MBA, Bharath Institute of Higher Education and Research, Chennai, India.

Email: chakravins@gmail.com
- Providing Training and advancement to the workers.

- Motivates and aides them for giving their earnest attempts.

- Controls the all out activity of the individuals inside association.

The targets of human asset improvement is to quicker human genius through edified and strong arrangements in instruction, preparing, wellbeing and work at all levels, from corporate to national Management[8],[10],[12].

Human asset the executives' target, then again, is to amplify the arrival on venture from the association's human capital and limit money related hazard. It is the obligation of human asset administrators in a corporate setting to lead these exercises in a successful, legitimate, reasonable, and reliable way. Let's talk about the absolute procedure of Human Resource Management in a short way to obvious its utilization in human asset advancement just as in preparing and improvement process.

\section{B. Human Resource Management}

Human resource management's objective, is to maximize the return on investment from the organization's human capital and minimize financial $\operatorname{risk}[13],[15],[17]$. It is the responsibility of human resource managers in a corporate context to conduct these activities in an effective, legal, fair, and consistent manner. Apart from this they also have to look after the human resource \& should manage them in a systematical manner by which they can create their effectiveness. The key functions that are used by the human resource managers in managing their $\mathrm{HR}$ are pointed out below:

\section{OBJECTIVES}

The expansive target of the investigation of approaches in IMFA is to consider the effect of preparing on the general expertise advancement of laborers[14],[16], [18].

The particular goals of the investigation are:-

- To analyze the viability of preparing in generally speaking improvement of ability of work power.

- To analyze the effect of preparing on the laborers.

- To study the progressions in personal conduct standard because of Training.

To measure the differential changes in yield because of Training. 
- To look at the cost adequacy in embedding Training Programmers.

\section{B. Scope of the Study}

1. The different preparing rehearses, modules, groups being pursued and restricted to the organization IMFA and its workers[19],[21],[23].

2. The diverse preparing projects encouraged in IMFA through its Faculties, outside offices or expert gatherings.

3. It additionally passes judgment on the upgrade of the information and aptitude of representatives and criticism on its viability.

\section{Limitations of the Study}

Detail concentrate is beyond the realm of imagination because of pool of time.

- Some of the workers would not uncover much data because of dread of their bosses.

- The test size was little because of time imperative which probably won't be genuine delegate of whole populace.

- Some of the respondents have not reacted completely.

- Biases may have crawled up with respect to the administration while furnishing responses.

\section{RESEARCH DESIGN}

So as to investigation the information basic measurable device like rate, normal and mean score were determined utilizing diverse factual apparatuses and a few inquiries were positioned utilizing scale. The information accumulation was for introduction. It comprises of arrangement of tables, charts, graphs. The introduction of information helps in translation of information[20],[22],[24]

Table - 1Training is of sufficient duration.

\begin{tabular}{|l|l|l|l|}
\hline SL.NO & PARTICULARS & RESPONDANCES & PERCENTAGE \\
\hline $\mathbf{l}$ & STRONGLYAGREE & 50 & 25 \\
$\mathbf{2}$ & AGREE NOR & 130 & 65 \\
$\mathbf{3}$ & NEITHER AGREE NIS & 5 \\
& DISAGREE & & \\
$\mathbf{4}$ & DISAGREE & 10 & 5 \\
$\mathbf{5}$ & STRONGLY DISAGREE & 0 & 0 \\
\hline
\end{tabular}

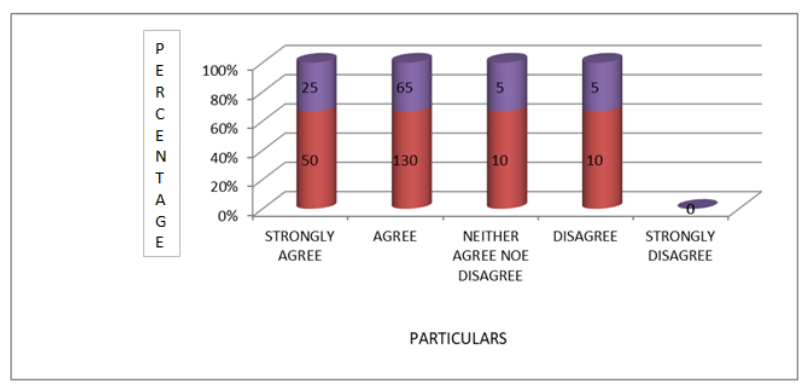

Figure-1Training is of sufficient duration.

Table - 2 Training program helpful in long run

\begin{tabular}{|l|l|l|l|}
\hline SL.NO & PARTICULARS & RESPONDANCES & PERCENTAGE \\
\hline $\mathbf{l}$ & STRONGLYAGREE & 60 & 30 \\
$\mathbf{2}$ & AGREE & 110 & 55 \\
$\mathbf{3}$ & NEITHER AGREE NOR & 20 & 10 \\
& DISAGREE & & \\
$\mathbf{4}$ & DISAGREE & 10 & 5 \\
$\mathbf{5}$ & STRONGLY DISAGREE & 0 & 0 \\
\hline
\end{tabular}

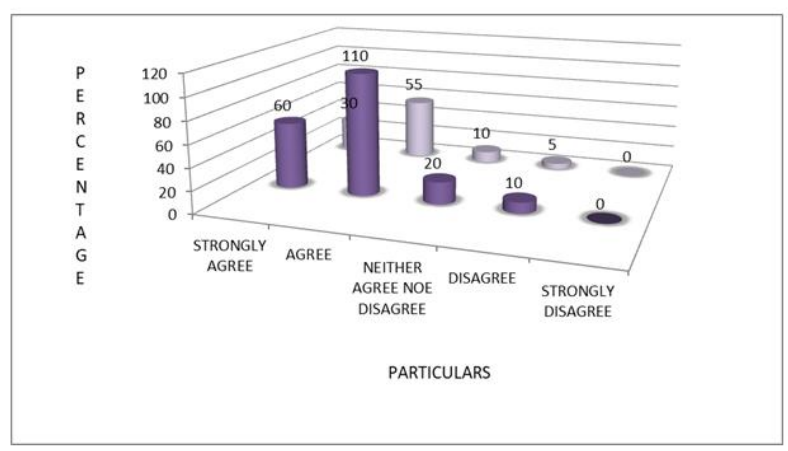

Figure - 2 Training program helpful in long run

Table -3 Training program helpful in personal growth

\begin{tabular}{|l|l|l|l|}
\hline SL.NO & PARTICULARS & RESPONDANCES & PERCENTAGE \\
\hline $\mathbf{1}$ & STRONGLYAGREE & 70 & 35 \\
$\mathbf{2}$ & AGREE & 100 & 50 \\
$\mathbf{3}$ & NEITHER AGREE NOR & 20 & 10 \\
& DISAGREE & & \\
$\mathbf{4}$ & DISAGREE & 10 & 5 \\
$\mathbf{5}$ & STRONGLY DISAGREE & 0 & 0 \\
\hline
\end{tabular}

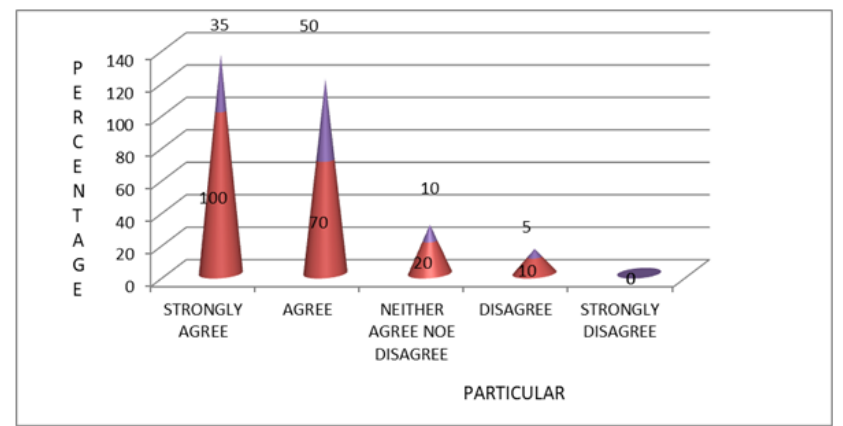

Figure - 3 Training program helpful in personal growth

Table -4 Faculty responses to trainees doubt.

\begin{tabular}{|l|l|l|l|}
\hline SL.NO & PARTICULARS & RESPONDANCES & PERCENTAGE \\
\hline $\mathbf{1}$ & STRONGLYAGREE & 50 & 25 \\
$\mathbf{2}$ & AGREE N NOR & 120 & 60 \\
$\mathbf{3}$ & NEITHER AGREE & 10 \\
& DISAGREE & & \\
$\mathbf{4}$ & DISAGREE & 10 & 5 \\
$\mathbf{5}$ & STRONGLY DISAGREE & 0 & 0 \\
\hline
\end{tabular}

Published By: 


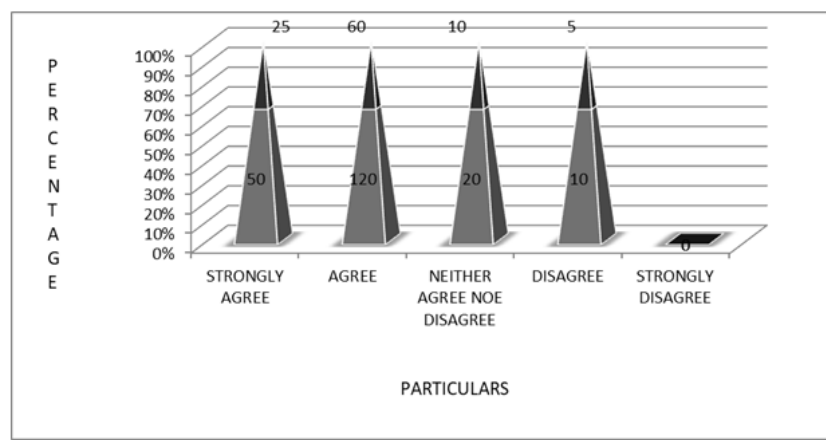

Figure -4 Faculty responses to trainees doubt.

\section{RESULTS}

The essential target of this examination study was to comprehend the connection between the representative of an association and their organization. This examination was directed on a gathering of 20 individuals of which there was a bigger nearness of male members as it were. The members comprised of an assortment of age gathering of individuals with a prevailing nearness of the family man working for around 6 years

With individuals from same occupations and fluctuating pay levels partaking in this investigation, we have discovered that a less one fourth of the populace are not happy with the preparation and improvement program directed by the organization. There is a solid inclination for preparing and advancement being sorted out by the organization improves them yet representatives needs the preparation and advancement program to be increasingly improved inoder to make them progressively effective laborers [25],[27],[29]

While a dominant part of individuals appear to know about offices being given to them feels that preparation causes them to improve the efficiency both quality and amount and most of them are happy with the preparation and advancement procedure directed and there are just couple of individuals insignificant individuals are not happy with procedure being led. Furthermore, even short of what one fourth of the populace neither concur nor can't help contradicting the announcements about preparing and improvement on which study has been led

Most of members are working in the organization or contributing themselves for at any rate at least 15 than that. They accept that preparation and advancement make vocation goals and preparing lessens their steady supervision on them which expands their certainty as it persuades them, make them proficient and makes them feel progressively sure about their employer stability. the fundamental objective for preparing and advancement procedure being led is comprehended by them and most of the workers pull out all the stops and they have faith in contributing themselves to the accomplishment of the organization[26],[28],[30]

In this above investigation $I$ infer that there are predominantly $70 \%$ of representative was for the most part fulfilled the Training and advancement procedure of IMFA, Therubali.

\section{V.DISCUSSIONS}

Training can give some intuitive sessions in preparing and advancement.

- The organization ought to receive some different ways for assigning the learners like preparing need recognizable proof overview, self designation, individual examination, hierarchical investigation and so forth.

- Training ought to be a nonstop procedure i.e., it ought to be granted as customary interims.

- The term of preparing project ought to be less and subtleties ought to be exact and precise.

- HR office should lead workshop on some essential subject with the goal that representatives are constantly spurred and urged to work.

\section{CONCLUSION}

The task report on preparing and improvement at Indian Metal and Ferro Alloys (IMFA) based on the examination made, the accompanying end are drawn:-

- Maximum number of the representatives finds solid condition at the work place.

- Lack of enthusiasm for representatives go about as a hindrance in preparing program

- Maximum workers said that they get help at whatever point they require.

- Employees are happy with the preparation and improvement projects given to them.

- The preparing system has helped in creating expertise of the worker.

- After going to the preparation program the greater part of the laborer discover their frame of mind better towards the activity.

- Most of the representative needs to the work environment to be overhauled where the instructional courses are been directed.

- Employees felt the time wastage during instructional meeting. in any case, students were happy with exercises led during preparing program since it was identified with their activity. 
- With individuals from same occupations and fluctuating salary levels taking part in this investigation, we have discovered that a less one fourth of the populace are not happy with the preparation and advancement program led by the organization.

There is a solid inclination for preparing and advancement being sorted out by the organization improves them yet at the same time representatives needs the preparation and improvement program to be increasingly improved inoder to make them progressively effective specialists[31],[33]

Most of members are working in the organization or contributing themselves for at any rate at least 15 than that. They accept that preparation and improvement make profession desires and preparing decreases their consistent supervision on them which expands their certainty as it propels them , make them effective and makes them feel increasingly sure about their employer stability. the principle objective for preparing and improvement procedure being led is comprehended by them and most of the workers pull out all the stops and they put stock in contributing themselves to the achievement of the organization

\section{REFERENCES}

1) BharthVajan R., Ramachandran S.,Psychographic dimensions of training,2016,International Journal of Pharmacy and Technology,V-8,I-4,P-23727-23729

2) Balakrishnan P., Bharthvajan R.,A study on human resource planning in hospitals in Chennai City,2014,International Journal of Applied Engineering Research,V-9,I-22,P-7503-7507

3) Priyadarsini P., Bharthvajan R.,Role of emotional intelligence training programme in reducing the stress of the nurses,2014,International Journal of Applied Engineering Research,V-9,I-22,P-7411-7421

4) Kerinab Beenu G., Bharthvajan R.,Empirical analysis on the cosmetic buying behavior of young women in South India,2014,International Journal of Applied Engineering Research,V-9,I-22,P-7361-7366

5) Balakrishnan P., Bharthvajan R.,Whistling in the wind,2014,International Journal of Applied Engineering Research,V-9,I-22,P-7586-7593

6) Krishnan B., Peter M.,Health hazards of Indian Bpo employee-an alarming issue, 2014,International Journal of Applied Engineering Research,V-9,I-22,P-7336-7341

7) Kerinab Beenu G.H., Peter M.,Role of insurance in economic development,2014,International Journal of Applied Engineering Research,V-9,I-22,P-7532-7539

8) Balakrishnan P., Peter M., Priyadarsini P.,Efficiency of safety measures for wellbeing of employees in manufacturing industry,2014,International Journal of Applied Engineering Research,V-9,I-22,P-7376-7382

9) Anbarasi M., Praveen Kumar S.,Online sales promotions of herbal products and its effectiveness towards tanisha.com,2019,Indian Journal of Public Health Research and Development,V-10,I-1,P-195-200

10) Anbarasi M., Praveen Kumar S.,Various online marketing and promotions strategies to improve the validation towards the organic products in the pharmaceutical sectors,2019,Indian Journal of Public Health Research and Development,V-10,I-1,P-263-269

11) Loganathan R., Praveen Kumar S.,Grievance handling a key factor for solving issues of employees in an organization,2014,International Journal of Applied Engineering Research,V-9,I-22,P-7483-7491

12) Loganathan R., Praveen Kumar S.,Study on preference of private label brands in super and Hypermarkets,2014,International Journal of Applied Engineering Research,V-9,I-22,P-7327-7335

13) Smitha M., Praveen Kumar S.,Understanding stress and its managementamong the nurses in Chennai city,2014,International Journal of Applied Engineering Research,V-9,I-22,P-7560-7565

14) Kerinab Beenu G.H., Praveen Kumar S.,A study on the investment behavior of Chennai investors in mutual fund schemes,2014,International Journal of Applied Engineering Research,V-9,I-22,P-7520-7525
15) Loganathan R., Praveen Kumar S.,Retention strategies key for organizational productivity,2014,International Journal of Applied Engineering Research,V-9,I-22,P-7443-7447

16) Pavithra J., Ganesan M., Brindha G.,State wise analysis of microfinance sector in India,2016,International Journal of Pharmacy and Technology,V-8,I-4,P-23417-23432

17) Pavithra J., Ganesan M.,A comparative study on microfinance in India and abroad,2016,International Journal of Applied Business and Economic Research,V-14,I-8,P-5471-5476

18) Pavithra J., Ganesan M.,A study on awareness and impact of micro-financial schemes,2016,International Journal of Applied Business and Economic Research,V-14,I-8,P-5449-5460

19) Senthilmurugan P., Pavithra J.,Consumer preference towards organised retailing with reference to Big Bazaar,2014,International Journal of Applied Engineering Research,V-9,I-22,P-7469-7475

20) Senthilmurugan P., Pavithra J.,Implication of social media marketing in growing healthcare industry,2014,International Journal of Applied Engineering Research,V-9,I-22,P-7448-7456

21) Loganathan R., Pavithra J.,Consumer perception towards private label brand over other brands in super markets and hypermarkets,2014,International Journal of Applied Engineering Research,V-9,I-22,P-7355-7360

22) Kerinab Beenu G., Pavithra J.,Tradeâ€"off between liquidity and profitability in logistics industry,2014,International Journal of Applied Engineering Research,V-9,I-22,P-7398-7401

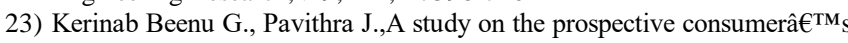
perception towards utility cars in Chennai city,2014,International Journal of Applied Engineering Research,V-9,I-22,P-7526-7531

24) Pavithra J., Dilli Babu P., Ambuli T.V.,A study on budgetary control at Maruti Service Masters, Chennai,2014,International Journal of Applied Business and Economic Research,V-12,I-2,P-151-161

25) Pavithra J., Dilli Babu P., Ambuli T.V.,A study on customer satisfaction of retro Garments Pvt Ltd, Chennai,2014,International Journal of Applied Business and Economic Research,V-12,I-2,P-381-391

26) Kerinab Beenu G.H., Pavithra J., Senthilmurugan P.,A study on the influence of promotional activities for TATA ARIA among consumers in Chennai,2014,International Journal of Applied Engineering Research,V-9,I-22,P-7572-7578

27) Vijayaragavan S.P.,An investigative expert that's general FBG sensors,International Journal of Mechanical Engineering and Technology,V-8,I-8,PP-1500-1505,Y-2017

28) Vijayaragavan S.P.,Equalization routing protocol for Wi-Fi sensor strategy,International Journal of Mechanical Engineering and Technology,V-8,I-8,PP-1662-1666,Y-2017

29) Karthik B., Kiran Kumar T.V.U., Vijayaragavan P., Bharath Kumaran E.,Design of a digital PLL using 0.35 $\hat{\mathrm{I}}^{1 / 4 \mathrm{~m}}$ CMOS technology,Middle East Journal of Scientific Research,V-18,I-12,PP-1803-1806,Y-2013

30) Kanniga E., Selvaramarathnam K., Sundararajan M.,Kandigital bike operating system,Middle - East Journal of Scientific Research,V

31) Jasmin M., Vigneshwaran T., Beulah Hemalatha S.,Design of power aware on chip embedded memory based FSM encoding in FPGA,International Journal of Applied Engineering Research,V-10,I-2,PP-4487-4496,Y-2015

32) Jasmin M.,Optimization techniques for low power VLSI circuits,Middle East Journal of Scientific Research,V-20,I-9,PP-1082-1087,Y-2014

33) Jasmin M., Vigneswaran T.,Fuzzy controller for error control of on - Chip communication,2017 International Conference on Algorithms, Methodology, Models and Applications in Emerging Technologies, ICAMMAET 2017,V-2017-January,I-,PP-1-5,Y-2017

\section{AUTHORS PROFILE}

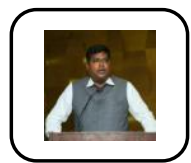

Dr S. Praveen Kumar Professor, Department of MBA, Bharath Institute of Higher Education and Research, Chennai, India.

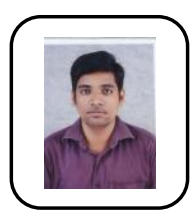

Mr.CS Gowtham Chakravarthi Assistant Professor, Department of MBA, Bharath Institute of Higher Education and Research, Chennai, India. 